\title{
Erratum zu: Soziale Herkunftseffekte in der Wahl der Hochschulform
}

\section{Anna Bachsleitner}

Online publiziert: 6. Mai 2020

(C) The Editors of the Journal 2020

\section{Erratum zu:}

\section{Z Erziehungswiss 2020}

https://doi.org/10.1007/s11618-020-00941-1

Tab. 3 war im Originalbeitrag leider nicht korrekt dargestellt. Korrekt muss die Tabelle wie folgt aussehen.

Der Originalbeitrag wurde korrigiert.

Die Online-Version des Originalartikels ist unter https://doi.org/10.1007/s11618-020-00941-1 zu finden.

A. Bachsleitner $(\bowtie)$

DIPF । Leibniz-Institut für Bildungsforschung und Bildungsinformation, Warschauer Str. 34-38, 10243 Berlin, Deutschland

E-Mail: Bachsleitner@dipf.de 


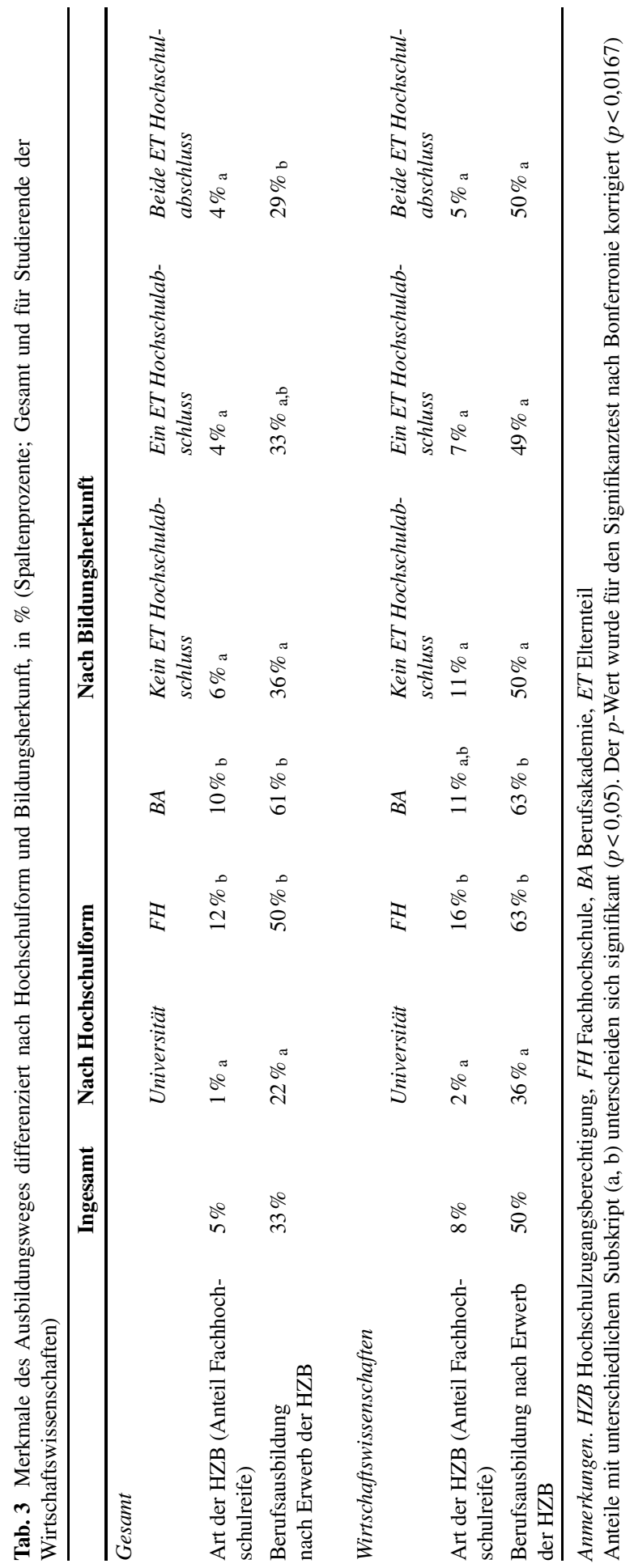

